\title{
Histological Study of Some Isolation Fungi from Iraq / Baghdad Hospitals Apparatus that affected in Liver, Kidney and Testes in Albino Mice
}

\author{
Lamyaa A. Fadhil ${ }^{1}$, Sara H. Seddiq ${ }^{2}$, Shaimaa A. Abid ${ }^{3}$, Nada F.Abaas ${ }^{4}$ \\ ${ }^{1}$ Baghdad University, Collage of Science, Biology Department \\ ${ }^{2,3}$ Baghdad University, Collage of Science for Women, Biology Department \\ ${ }^{4}$ Collage of Madenat Alelem University, Anesthesia and Intensive Care Department
}

\begin{abstract}
Some fungi were isolated from some hospitals in Baghdad (Al-Furat General Hospital and Al-Yarmouk Teaching Hospital),For the purpose of isolating and diagnosing fungi on the center of Czapeck Dox Agar, it was noted that Aspergillus was one of the most common fungi found in the hospital. The prevalence rates in the Al-furat General Hospital were $56 \%$ for the rest of the fungus species, and A.flavus fungi was $45.5 \%$, mostly in female lobbies and A. fumigatus $31.05 \%$, mostly from containers. The results of isolating from Yarmouk Hospital showed that A.fumigatus was $44.45 \%$ and $25.24 \%$. After isolation and diagnosis, the fungus extracted was stimulated to male mice with a rate of 30 mice divided into three groups each group consisted of ten mice. The first group was control group and the second group was the $0.1 \mathrm{ml}$ group of A. Flavus extract and the third groups were given $0.1 \mathrm{ml}$ of A. Fumigatus extract. The experiment lasted for 30 days. The study also showed dilated as congestion in the central vein and inflammatory cells infiltration, show accumulation fat in liver tissue. Hypertrophy tissue, it is observed that necrosis in hepatic cells.In organ kidney different histological changes included infiltration, congestion in central vein. Renal degeneration in the kidney tissue, atrophy of renal tubule. While histological changes that found in the testes including damages of sertoli cells, degeneration of Leydig cells .
\end{abstract}

Keywords: A.flavus, A. fumigatus, Aflatoxin, Baghdad hospitals, Necrosis, Infiltration, Hypertrophy

\section{Introduction}

Hospitals are the ideal place to receive patients who have access to appropriate health care, apart from the systemic injuries they receive as a result of fungal infections. Despite the hospital's methods of sterilizing the soil and containers in the screening process, the infections acquired by the hospitals of a century is a critical problem that affects the quality of health care provided in hospitals where $20 \%$ of this infection can be avoided by polluting fungi that contaminate terrestrial and other health facilities [1,2].

High rates of microbiology such as fungi in hospitals are a worrying and increasing concern for many acute, infectious and sensitive diseases caused by such vital diseases [3]. These percentages also provide an indication of the degree of hygiene of hospitals that carry different types of microbiology due to failure to meet the health conditions that limit of the appearance of microscopic cells in the most complex locations). It is therefore important to know the presence of these markers in different areas of the hospital and to implement monitoring programs to assess the effectiveness of infective techniques that can be applied and contribute to protective measures Virtue against diseases. The species include many species, most of which live on organic materials such as food and grains. Some species cause toxicity due to the production of these species of toxins, such as aflatoxin, produced by the genus A. Niger, and some species of selective parasitic species cause some infectious diseases such as dermatitis Ear infections, respiratory tracts and pulmonary aspergillosis which is caused by some species of A. niger [4] Aspergillus are produce the aflatoxin, There are several types of aflatoxins (B1, B2, G1, G2), but the more toxic is aflatoxin type (B1) ,because $(2.2 \mathrm{mg})$ from this toxic caused liver damage [5]. Therefore, the study aimed at isolating and diagnosing the types of fungi from the floors of the baths, chambers and waste containers from some government hospitals in Baghdad to study the histopathological effects caused in liver, kidney and testes.

\section{Materials and methods}

A) Collection of samples:

20 samples were collected in (Al-Furat General Hospital and Al-Yarmouk Teaching Hospital), specifically from several different places of the hospital to identify the types of fungus found. Transport media collected the samples below in the hospital and the rate of three replicates per place was in cold boxes from the hospital to the laboratory and as follows:

1. Bathrooms floor.

2. Waste containers. 


\section{International Journal of Science and Research (IJSR) \\ ISSN (Online): 2319-7064 \\ Index Copernicus Value (2016): 79.57 | Impact Factor (2015): 6.391}

3. Lanes.

4. Patients' beds.

5. Ground floor

B) Preparation of plant culture:

Supplemented with $50 \mathrm{mg} / \mathrm{L}$ of antibiotic I told

Sabouraud's Dextrose Agar Under sterile conditions, the samples taken from the hospital were placed in the incubator $25 \mathrm{~m}$ for a week.

C) Diagnosis of fungi:

After examination by Czapeck Dox agar to the center of Aspergillus after a week were transferred types of fungus Microscopy to be diagnosed based on the fungal

classification key.[6,7]

D)Experimental animals:

Thirty animals were used in the current experiment at age 810 weeks and at a mean weight of 25-30 g ,were transferred to private cages within the animal house of the Faculty of Science for women / University of Baghdad and were cared for by giving them. Water and the leaves were left for ten days before induction under the laboratory conditions of $25^{\circ}$ C, a period of light and dark 12 hours:

G1: the control group was left to take water and the length of the experiment

G2: $0.1 \mathrm{ml}$ dose of Aspergillus Flavus fungus suspension was given daily orally as well as the juice and water.

G3: $0.1 \mathrm{~mL}$ dose of Aspergillus Fumigatus fungus

suspension was given daily orally as well as juice and water.

\section{E)Animal sacrifice}

All animals were killed by spinal dislocation, liver , kidney and testes were removed for histological studies. Tissues were fixed in $10 \%$ formalin, embedded in paraffin and cut into sections which stained with hematoxylin and eosin and examined microscopically. [8]

\section{Results}

1. The fungi that were isolated from Al-Furat General Hospital :

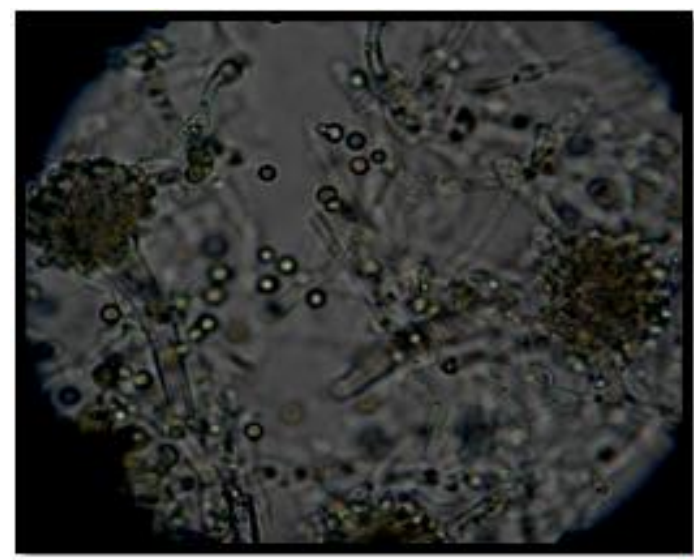

Table (1): Type of fungi and place of collected from hospitals:

\begin{tabular}{|c|c|c|c|}
\hline No. & Apparatus & $\begin{array}{c}\text { Yarmouk } \\
\text { Teaching Hospital }\end{array}$ & Al-Furat General Hospital \\
\hline 1 & ECG & $\begin{array}{c}\text { A.fumigatus } \\
\text {,A.flavus , A.niger }\end{array}$ & $\begin{array}{c}\text { A.flavus, A.fumigatus } \\
\text {,A.granulomus } \\
\text {,A.parasiticus ,A.ochoratus }\end{array}$ \\
\hline 2 & Sonar & $\begin{array}{c}\text { A.fumigatus } \\
\text {,A.flavus, A.niger }\end{array}$ & $\begin{array}{c}\text { Afumigatus , A.flavus , } \\
\text { A.ochoratus }\end{array}$ \\
\hline 3 & The dialysis & $\begin{array}{l}\text { A.granulomus } \\
\text {,A.fumigatus }\end{array}$ & $\begin{array}{c}\text { A.versicolor ,A.fumigatus, } \\
\text { A.flavus, A.ochoratus }\end{array}$ \\
\hline 4 & the beded & $\begin{array}{c}\text { A.flavus, } \\
\text { A.fumigatus, } \\
\text { A.granulomus }\end{array}$ & $\begin{array}{c}\text { A.niger, A.flavus, } \\
\text { A.parasiticus, } \\
\text { A.fumigatus }\end{array}$ \\
\hline 5 & $\begin{array}{l}\text { Stress and } \\
\text { diabetes }\end{array}$ & $\begin{array}{l}\text { A. Fumigatus } \\
\text {,A.flavus }\end{array}$ & $\begin{array}{c}\text { A. Fumigatus } \\
\text {,A.flavus,A.parasiticus }\end{array}$ \\
\hline
\end{tabular}

Table 2: The percentage of species recurrence and the rate of appearance of the types of Aspergillus in Al-Furat General Hospital

\begin{tabular}{|c|c|c|c|}
\hline No. & Type of fungi & $\begin{array}{c}\text { Percentage of } \\
\text { frequency of type }\end{array}$ & $\begin{array}{c}\text { The percentage of the } \\
\text { appearance of the species }\end{array}$ \\
\hline 1 & A.flavus & $44.5 \%$ & $25.6 \%$ \\
\hline 2 & Afumigatus & $30.05 \%$ & $22.75 \%$ \\
\hline 3 & A.parasiticus & $15.1 \%$ & $19.37 \%$ \\
\hline 4 & A.ochoratus & $6.78 \%$ & $18 \%$ \\
\hline 5 & A.versicolor & $3.4 \%$ & $13.2 \%$ \\
\hline
\end{tabular}

Table3: The percentage of the type of recurrence of the emergence of sparlic species in Yarmouk Teaching Hospital

\begin{tabular}{|c|c|c|c|}
\hline No. & Type of fungi & $\begin{array}{c}\text { Percentage of } \\
\text { frequency of type }\end{array}$ & $\begin{array}{c}\text { The percentage of the } \\
\text { appearance of the species }\end{array}$ \\
\hline 1 & A.fumigatus & $45.45 \%$ & $22.4 \%$ \\
\hline 2 & A.flavus & $24.24 \%$ & $44.2 \%$ \\
\hline 3 & A.granulomus & $21.21 \%$ & $18.2 \%$ \\
\hline 4 & A.niger & $9.09 \%$ & $15.3 \%$ \\
\hline & & & \\
\hline
\end{tabular}

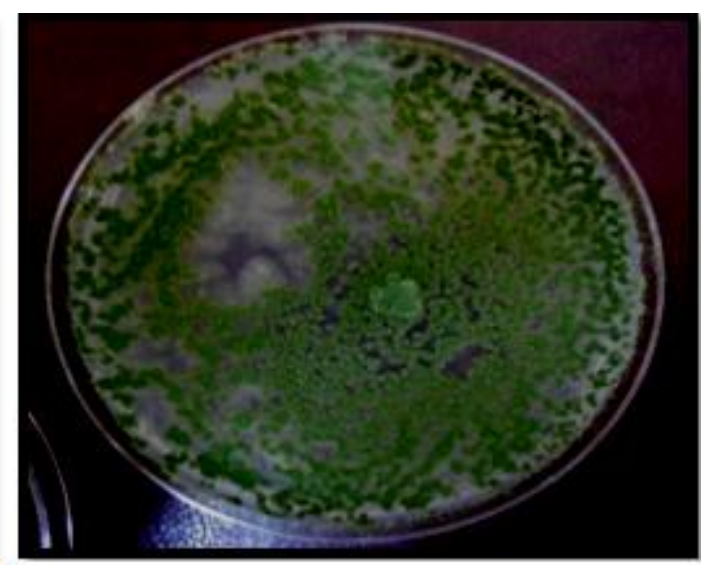

A

Volume 6 Issue 12, December 2017

www.ijsr.net

Licensed Under Creative Commons Attribution CC BY 



B

Picture 1: Some isolate fungi species from hospitals. Right and left colonies showing fungi A -A.flavus, B- A.fumigatus.

\section{4) Histological Change}

The light microscopic study of the control group of the liver tissue can see in (fig.1), A sectional view of treated mice showed dilated as congestion in the central vein and inflammatory cells infiltration as (fig.2), show fatty degeneration in liver tissue (fig.3).hypertrophy tissue as (fig.4).We can see necrosis in hepatic cells in(fig. 5).In organ kidney we can see control group In (fig.6).Different histological changes found in tissues of kidney included infiltration, congestion in central vein (fig.7).renal degeneration in the kidney tissue in (fig.8), atrophy of renal tubule in (fig.9). While histological changes that found in the testes of test group in comparison to control group (fig.10) including damages of sertoli cells (fig.11), and degeneration of Leydig cells in (fig.12)

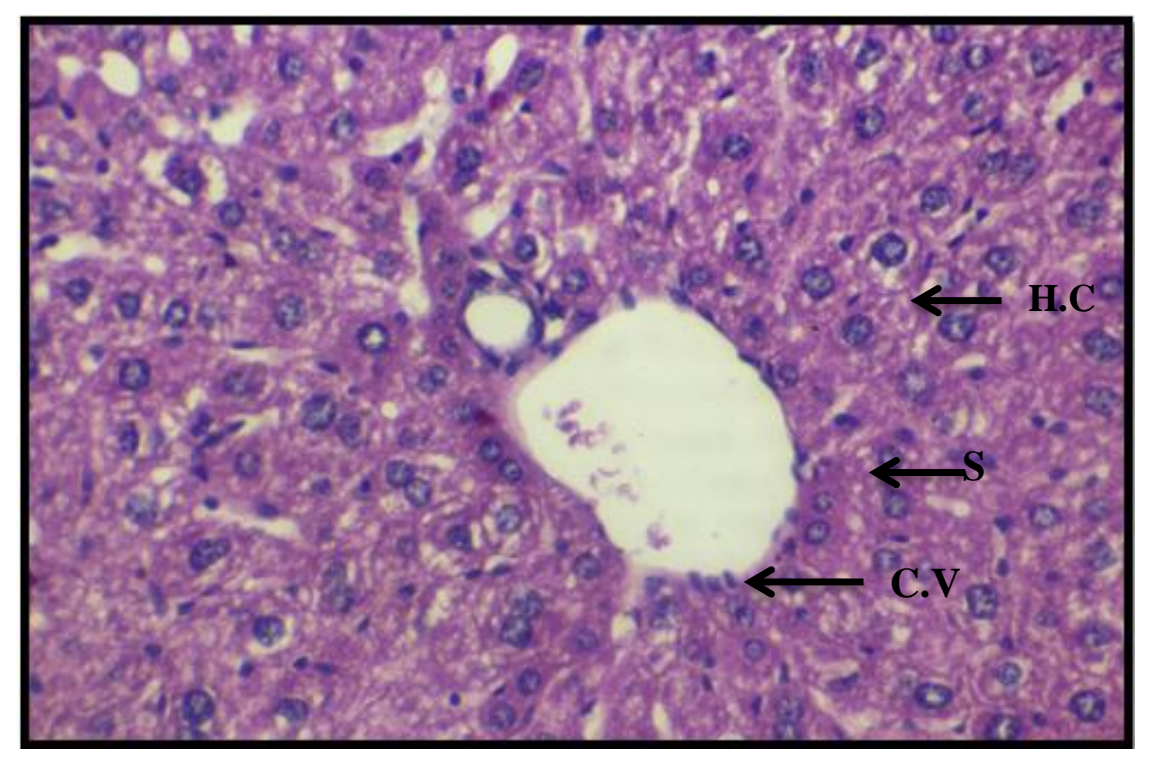

Figure 1: a section in the liver of control animal shows: central vein $(\mathbf{C V})$, hepatic cell (H.C) and sinusoids of blood (S). (H\&E, 400X)

Volume 6 Issue 12, December 2017

www.ijsr.net

Licensed Under Creative Commons Attribution CC BY 


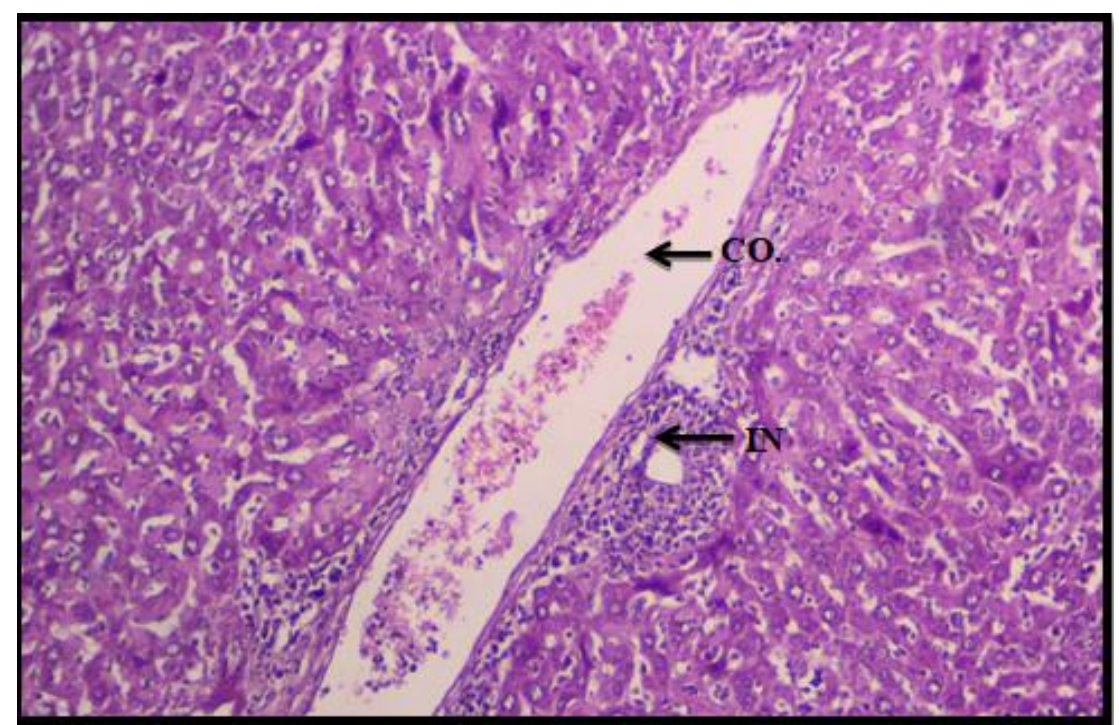

Figure 2: a section in the liver shows: congestion of vein (CO.) and infiltration of inflammatory cells (IN.). (H\&E, 400X)

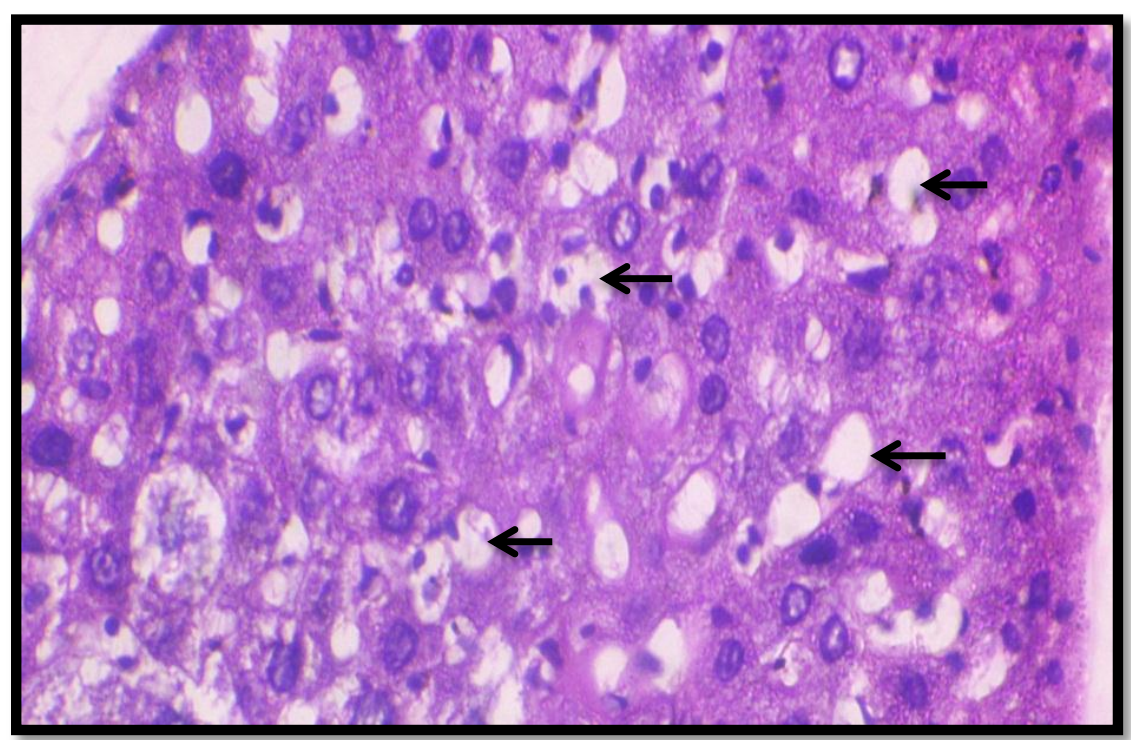

Figure 3: a section in the liver tissue of animal shows fatty degeneration $(\rightarrow$, ( H\&E, 400X)

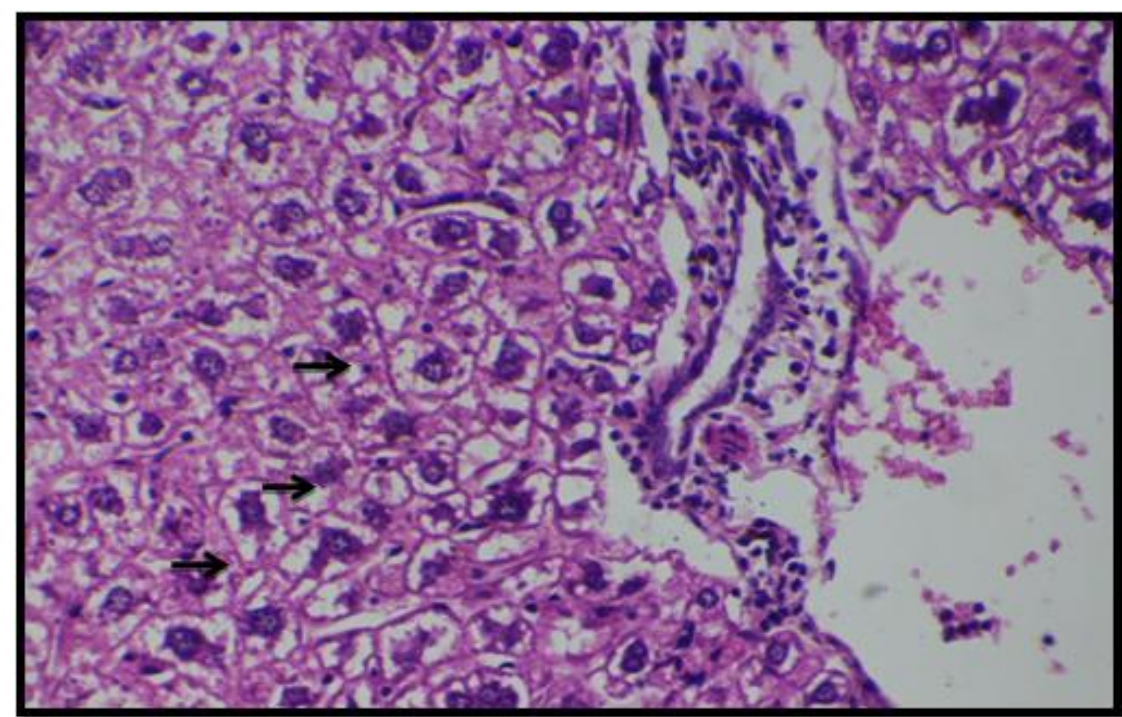

Figure 4: A section in the liver tissue of animal show: hypertrophy of the cells $\rightarrow$ ), (H\&E, 400X)

\section{Volume 6 Issue 12, December 2017}

www.ijsr.net

Licensed Under Creative Commons Attribution CC BY 




Figure 5: a section in the liver tissue of shows: necrotic tissue, $(\rightarrow),(\mathrm{H} \& \mathrm{E}, 400 \mathrm{X})$

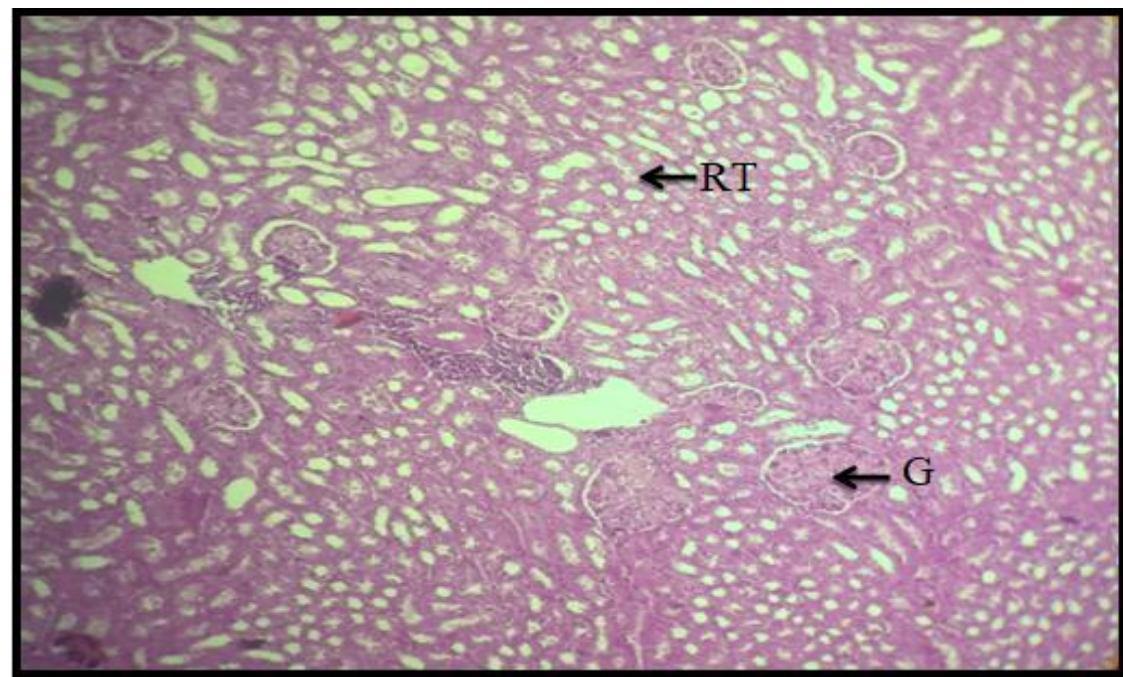

Figure 6: a section in the kidney of control animal shows: Glomerular (G), Renal tubule (RT).(H\&E, 100X)

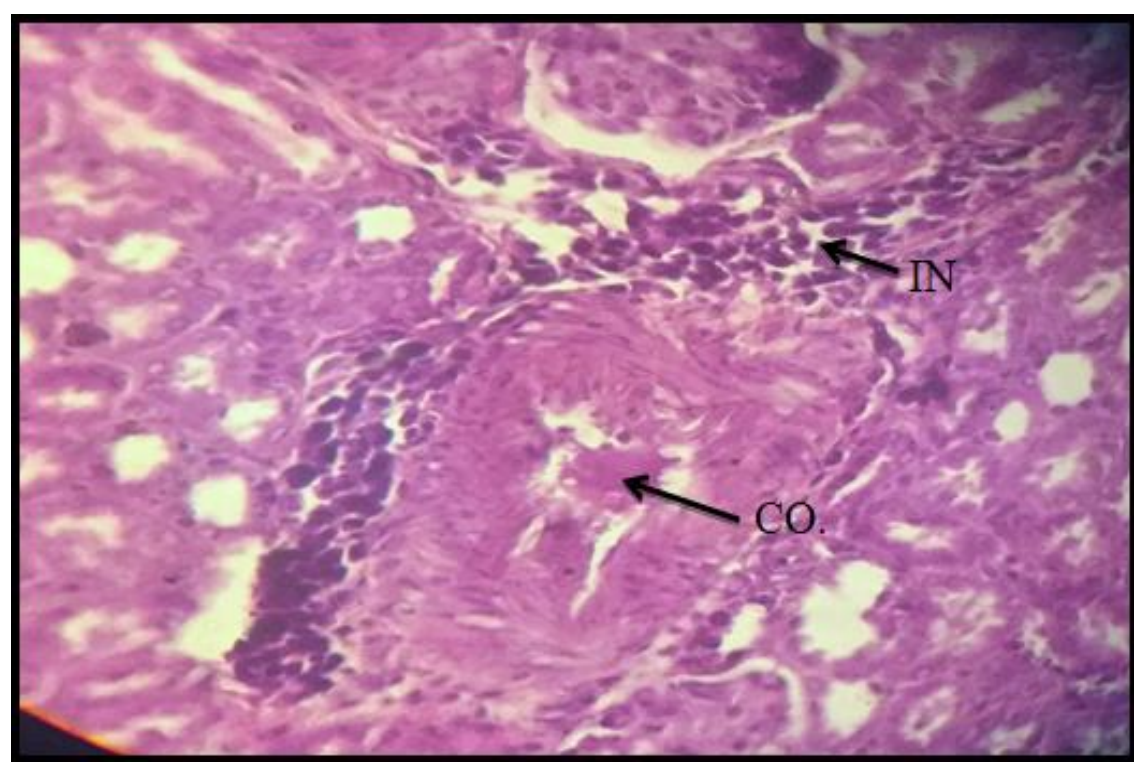

Figure 7: A section in the kidney shows: congestion (CO.) and infiltration (IN.). (H\&E, 400X)

\section{Volume 6 Issue 12, December 2017} www.ijsr.net

Licensed Under Creative Commons Attribution CC BY 


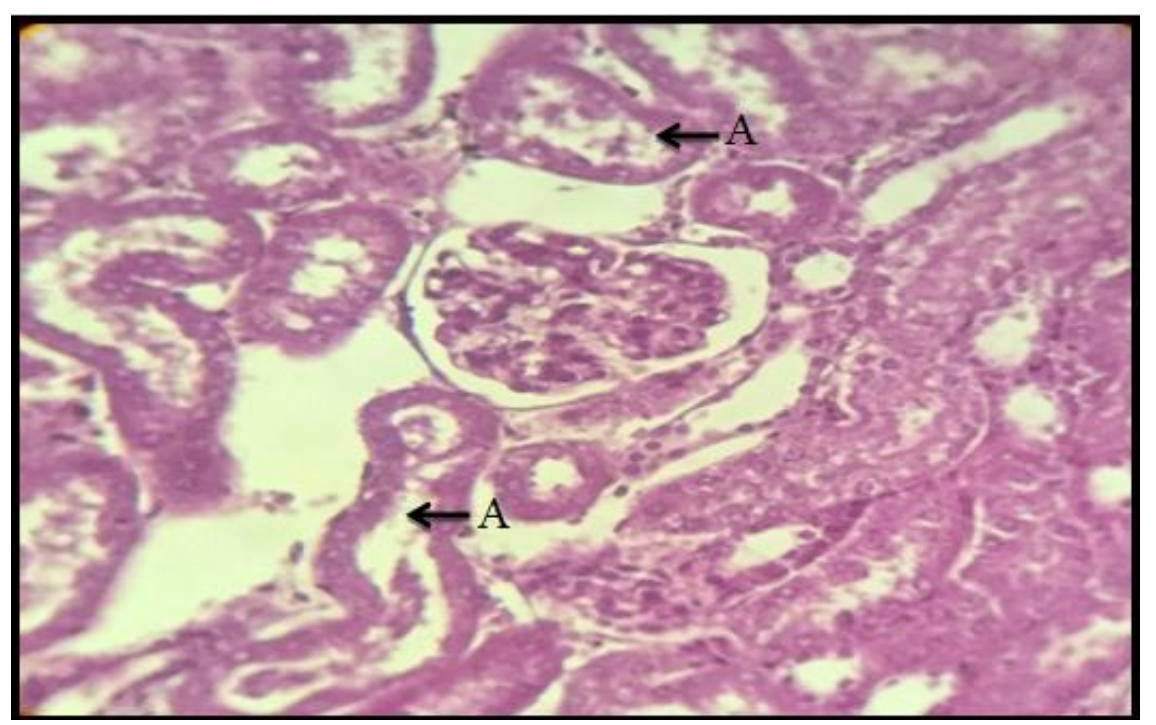

Figure 8: a section in the kidney shows: Atrophy of renal tubule (A.) (H\&E, 400X).

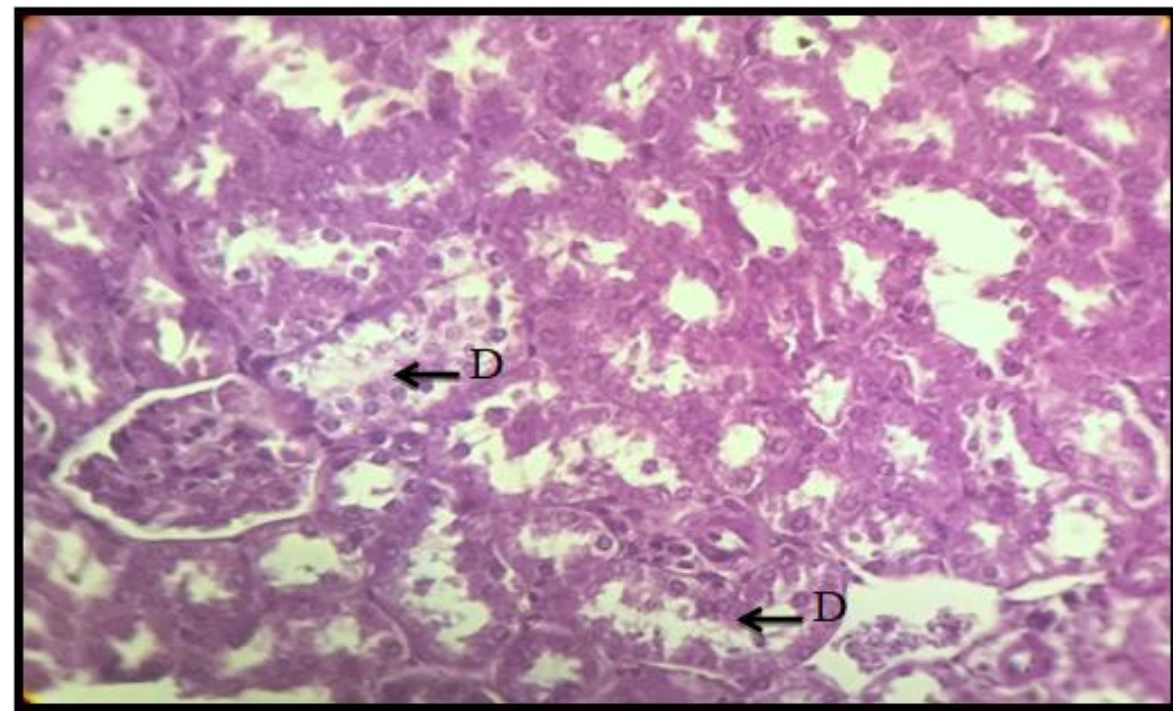

Figure 9: a section in the kidney shows: Degeneration of renal tubule (D.) (H\&E, 400X)

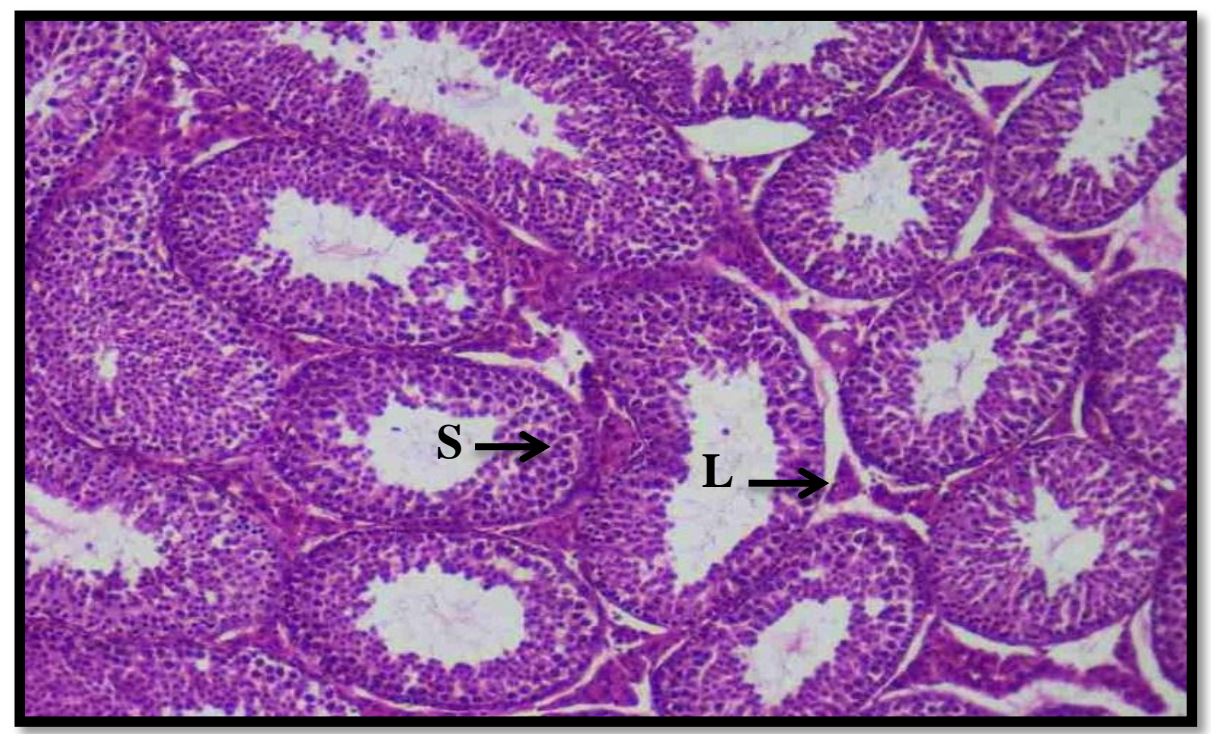

Figure 10: A section in seminiferous tubule shows: leydig cells (L.), sertoli cells (S) (H\&E, 100X)

\title{
Volume 6 Issue 12, December 2017
}

\author{
www.ijsr.net
}

Licensed Under Creative Commons Attribution CC BY 


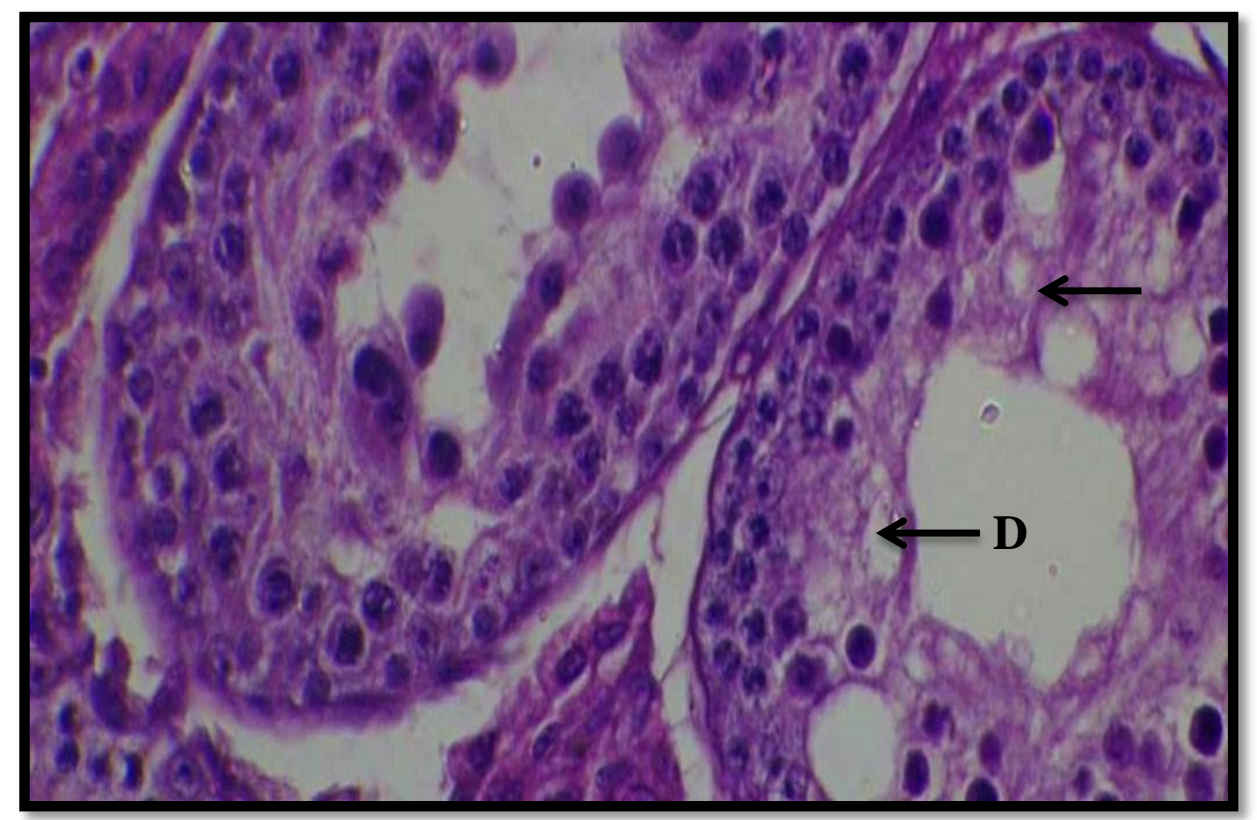

Figure 11: A section in seminiferous tubule Shows: Degeneration of sertoli cells (D.) (H\&E, 400X)



Figure 12: A section in seminiferous tubule shows: Degeneration of leydig cells (D.), (H\&E, 400X)

Volume 6 Issue 12, December 2017

www.ijsr.net

Licensed Under Creative Commons Attribution CC BY 


\section{International Journal of Science and Research (IJSR) ISSN (Online): 2319-7064}

Index Copernicus Value (2016): 79.57 | Impact Factor (2015): 6.391

\section{Discussion}

The results of the collection of samples from some hospitals in Baghdad (Yarmouk Hospital and AlFurat General Hospital) showed the emergence of species of Aspergillus as in Table (1), observed when collecting samples the emergence of other races such as:

A.versicolor, A.ochoratus,A.parasiticus,A.granulomus . The percentage was less than the Aspergillus fungi, A. fumigatus was $30.05 \%$ and A.flavus fungi are more prevalent, at $44.5 \%$. as in Table $(2,3)$. It was found that the percentage of the emergence of the Aspergillus was $65 \%$ for other species, because of the large number of spores. Likewise, the ability of fungi tolerates inappropriate conditions at a temperature above (45c) and its ability to cause damage to the human body Skin, lungs, and liver are affected due to the presence of virulent agents that are harmful to humans, especially patients who are hospitalized [9].

Aspergillus is a pathogenic organism that causes the weakness in the immune system, and has several pathways to enter the body, infect the various organs and enter the bloodstream and then the injury of the liver organ. The current study has showed changes in the tissue of the liver and kidney organs, including venous congestion and leukocyte infiltration. The emergence of vacuoles in cytoplasm cells hepatic and necrosis of hepatic cells is due to the metabolic product of the fungus which produces (Aflatoxins) from Aspergillus fungi. These toxins are on several types including (B1,B2,G1,G2), [10], While the G1 toxins are more dangerous than $\mathrm{B} 1$ on the liver, but B1 toxins are more dangerous than G1 on kidneys[11]. G1 toxins affect the permeability of the plasma membrane and lead to vacuoles in hepatic and renal cell It was observed that oral administration of G1 poisoning caused liver cancer and renal nephropathy caused by these toxins [12].The study has improved that AF toxins cause degeneration and atrophy in tubules of kidneys, causing increased creatinine concentration as a result of increased muscular release and a decrease in release from the kidney [13].

One of the side effects of isolated fungi its effect on the testes. Treatment with AF toxins causes a decrease in the thickness of the germicidal layer of the sperm. [14].These toxins destroy the sertoli cells, causing a decrease in the secretion of Inhibin, that affects the pituitary gland causing inhibition or decrease in FSH secretion [15]. AF toxins cause the destruction of leydig cells, causing a decrease in the concentration of testosterone in the blood [16,17]. The cause is the accumulation of these toxins in the pituitary gland, which leads to a decrease in the secretion of LH, affects the cells of leydig to stimulate the secretion of testosterone [18].

\section{References}

[1] Haley, R, Culver, D. H. \& White, J. W. (1985). The efficiency of infection surveillanceand control program in preventing infections in US hospital. Am J Epidemiol, 121(2), 182-205.

[2] Harbath S, Sax H , Gastmeier p.( 2003 ). The preventable proportion of nosocomial infections: an overview of puplished reports. J. Hos. Infect. ; 54_258.

[3] Lugauska, A., \& Krikstaponis, A. (2004). Filamentous fungi isolated in hospitals and somemedical institutions in Lithuania Indoor Built Environment. SAGE journal, 13(2),101-113.

[4] Shukri, M. M. (1991). The basics of fungi and plant diseases. Dar al-Hikma Press for printing and publishing Mosul, First Edition, 32-34.

[5] Ahmed, A. (2006). Environmental Pollution (References,Effects, fight,control). Dar global_alqahrh library, 35-42.

[6] Weinstein, A. \& Berman, B. (2002). Topical treatment of common superficial Tinea infections. American Family Physician. Rev. 1-10 .

[7] File, T. M. \& Tan, J. S.(1991). Bacterial skin and soft tissue infections. J. Gynecol. 172 : 17-24. J. Lancet. $1: 164-168$

[8] Bancroft,J.D.and Gamble, M. (2008) . Theory and practices of histological technique. $16^{\text {th }}$ ed . Churchill Livingstone Elseivier . Philadelphia .PP:56 .

[9] Kwon-chung, J. \& Bennette, E. (1992). Medical Mycology. Lea and febiger, 244836.

[10] Anamika Jha , Krithika,R .Manjeet,D . Ramtej J. Verma . ( 2013) . Protective Effect of Black Tea Infusion on Aflatoxin Induced Hepatotoxicity in Mice . J. OF Clinical and Experimental Hepatology .3 (1) $: 29-36$.

[11] International Agency for Research on Cancer (IARC) - Summaries \& Evaluations .(2002) . 82 ( 1 ) : pp :171 .

\section{Volume 6 Issue 12, December 2017} www.ijsr.net 


\section{International Journal of Science and Research (IJSR)

[12] Theophilus K U, Chukwugozie N O and Ezinne U A . (2013) . Effect of Aspergillus flavus on the Liver of Experimental Rats Administered with Antiretroviral Drugs . American J .of Phytomedicine and Clinical Therapeutics . 1 ( 6 ) : $443-456$.

[13] Yassein, S. \& Zghair, Z. R. (2012). Study of Toxicity and Pathogenicity ofAflatoxin B1 and G1 in Mice. Al-Anbar J, 2(1), 23-31.

[14] Hasanzadeh, Sh . Hosseini, E. and Rezazadeh, L.(2011) . Effects of aflatoxin B1 on profiles of gonadotropic (FSH and LH), steroid (testosterone and 17 $\beta$-estradiol) and prolactin hormones in adult male rat . Iranian Journal of Veterinary Research, Shiraz University . 12 ( 4 ) : $332-336$.

[15] Padhy N, Latha M, Sathya B and Varma TR. (2009) . Antral follicle size in the downregulated cycle and its relation to in vitro fertilization outcome. J . Hum . Reprod . Sci. 2 (2) : $68-71$.

[16] Aydiner A, Aytekin Y. and Topuz, E .( 1997 ). Effects of cisplatin on testicular tissue and the Leydig cell-pituitary axis. Oncology . 54 (1) : $74-80$.

[17] Murad, A. .F., ahmed, S. \& Abead, S. (2015). Toxicity Effect of Aflatoxin B1 onReproductive System of Albino Male Rats. Pakistan Journal of Biological Sciences, 18(3), 107-114.

[18] Verma RJ1 and Nair,A . (2002) . Effect of aflatoxins on testicular steroidogenesis and amelioration by vitamin E. Food Chem . Toxicol. 40 (5) : $669-672$.

Volume 6 Issue 12, December 2017 www.ijsr.net 